\title{
CONAMED as a Mediation Strategy the Development of the Medical Act
}

La mediación como estrategia de la CONAMED en el acto médico

\author{
Lydia López-Pontigo ${ }^{a}$, María del Refugio Acuña-Gurrola ${ }^{b}$, Bertha M. Pimentel-Pérez ${ }^{c}$, Iván
}

Hernández-Pacheco ${ }^{d}$

\begin{abstract}
:
In the medical practice, several elements like science and technology that are also linked to the use of knowledge and values, which set the relationship physician-patient, aim at offering well-being to the population. This demands professional health care staff with a competent training to serve them. However, sometimes this duo becomes devalued due to several factors like malpractice leading to a medical complaint. Is in this scenario that CONAMED plays an important role with its strategy of mediation offering alternative methods to solve disputes or conflicts within the medical practice.
\end{abstract}

Keywords:

Medical practice, mediation strategies

\section{Resumen:}

En el ejercicio de la práctica médica interactúan diversos elementos como la ciencia y tecnología que a su vez se vinculan con el uso de conocimientos y valores, los cuales configuran la relación médico-paciente, cuyo principal objetivo es ofrecer bienestar a la población, lo cual demanda que el profesional de la salud tenga una formación integral competente para estar al servicio de ellos. Sin embargo, en ocasiones dicho binomio se desvirtúa derivado por múltiples factores entre los que se encuentra la mala praxis que deriva en una queja médica. Ante esta panorámica es que emerge la función de la CONAMED como principal estrategia de mediación para proporcionar mecanismos alternativos para la resolución de controversias o conflictos en el ejercicio profesional de la medicina.

\section{Palabras Clave:}

Acto médico, estrategias de mediación

\section{The medical practice}

Today, users perceive a health care characterized by negative aspects based on malpractice, inappropriate attitude and a lack of values in their professional development, rather than on a bad technical-scientific performance.

In this scenario rises the need to conceptualize and characterize the medical practice to analyze disputes and divergences between what it is and what it should be.

According to scientific bibliography, the medical practice is conceptualize from two different perspectives: normative and academic. According to the first one, various authors define the medical practice as follows.

\footnotetext{
a Lydia López Pontigo, Universidad Autónoma del Estado de Hidalgo, Instituto de Ciencias de la Salud, https://orcid.org/0000-0001-69017900, Email: lydial@uaeh.edu.mx

${ }^{\mathrm{b}}$ María del Refugio Acuña Gurrola, Universidad Autónoma del Estado de Hidalgo, Instituto de Ciencias de la Salud, https://orcid.org/00000003-3194-5392, Email: maria_acuna@uaeh.edu.mx

c Bertha Maribel Pimentel Universidad Autónoma del Estado de Hidalgo, Instituto de Ciencias de la Salud, https://orcid.org/0000-0002-52666803, Email: bertha_pimentel@uaeh.edu.mx

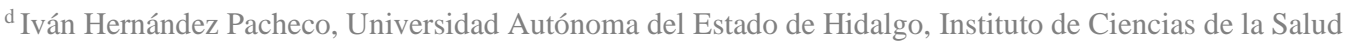


For Orrego (1), it is a set of actions that go from a simple diagnosis to a very complex surgery, implying an overload of risks as there are no concrete elements nor objectives that allow having an exact result.

For Besio (2), it is an elective action carried out by an expert whose objective is the health of the patient; besides searching for sickness prevention or recovery of health, this being considered as a mankind's asset.

Finally, for Laín (3), it is the content of each moment spent between physician and sick person characterized for being uninterrupted, that is, the time spent with patients in different spaces like private office, an outpatient doctor's office at a public clinic or a university private hospital, etc.

Regarding the normative dimension, the three conceptual approaches allow to define it as the proper interaction between useful information given by the patient, and on behalf of the physician, develop an empathic and responsible attitude to understand the set of behaviors that allow the patient to give necessary information to accurately interpret the given data.

Once the medical practice has been conceptualized, it is necessary to consider which are its main characteristics. The medical practice has the following characteristics:

- $\quad$ Professionalism: It can only been carried out by health care staff duly qualified and certified.

- $\quad$ Standardized performance: in terms of the lex artis ad hoc, the health care staff can only carry out actions clearly valid according to commonly accepted medical literature.

- Legal purpose: The medical practice is legitimate when it is performed in accordance with the law, the lex artis ad hoc and when the informed consent form of the patient or his/her legal representative has been collected.

- Not formal: it does not require the formal hiring of the services. Regardless of the previously mentioned, the documentation of the medical practice is mandatory in the clinical file, in terms of the Regulations to the General Law of Health, with respect to medical attention, and in terms of the official Mexican standards NOM-004-SSA32012, the clinical file NOM-024-SSA3-2012, Systems of Registry Information for Health.
There are several types of physician-patient relationships that can be classified as follows:

- Paternalistic. The physician decides for the patient.

- Informative. The decision depends only on the patient.

- Interpretative. The physician interprets and makes sure that the information given to the patient is understood, and he/she tries to assume the values of the patient.

- Deliberative. The patient analyses through a dialogue the different values related to health, their importance and the instructions for treatment.

\section{Mediation}

When questioning what mediation has to do with health, it is necessary to refer to the "conflict", which has been present in different contexts of human life and the medical field is not an exception. So, before the different agreements or disagreements of the medical practice, strategies that allow to tackle the conflicts are searched, this is why Vinyamata (4) considers "mediation" as the ideal strategy that allows the art of mediating, interceding, pleading in conflict situations.

To have a concrete example about mediation, it is necessary to mention that mediation is considered as a polysemic term for the following reasons (4):

1. Origin: it is necessary to mention that mediation is a term that emerges in the legal field, and later it has been adopted in other fields like medicine, psychology, education, etc.

- It is identified that mediation raises as an alternative tool for conlfict solution in the legal field. Therefore, mediation demands the intervention of a an impartial third party who helps solving the conflict.

- So, from a general perspective, mediation can be understood as an agreed cooperation so everyone wins when solving any type of conflict.

2. Normative character: mediation formally exists since no more than 10 years ago in Mexico. Mediation was not mentioned until 2005 with the 
reform to the Article 18 of the Constitution to establish the implementation of alternative methods in the criminal field, with the purpose of offering a reparatory justice option at a constitutional level. With a greater support, in 2008, the implementation of alternative methods of conflict solution was extended to other fields with the reform to the Article 17 of the Constitution. With this legal framework "mediation" gets a formal character in the Mexican context and it started to be regulated in several states of the country, although today, only 23 states have materialized these proposals.

3. Multidisciplinary character: Because it can be applied in different fields like law, medicine, psychology, education.

4. The term "mediation" has different meanings that can be confusing and sometimes it is defined as a synonym of conciliation, education in values, therapy, counselling, and coaching.

In general, with the previous referents, it can be seen why mediation is a polysemic concept, as it has different edges for its explination and/or understanding.

From a general perspective, mediation can be defined from the Vallejo \& Guillén's side (5) as a confidential, voluntary and structured process of conflict solution useful for both parts that are involved in the conlfict to satisfactorily solve their conflict, accepting the help of a professional who is an expert and duly trained in mediation, whose main characteristics are to be impartial and that he/she does not impose agreements but guides both parts to accomplish a same objective, in a balanced and fair way.

The previous definition allows identifying that mediation can be defined according to different elements that have been gathered with the purpose of having a better understing of it. For an accurate definition (5), five essential elements of mediation are taken into account:

1. The mediator has no power of making decisions.

2. The mediator helps, advices, and facilitates a voluntary conlfict solution that will benefit both parts.

3. The mediator has an impartial attitude.
4. The mediator invervenes by petition of th parties.

5. The mediator end his/her intervention by getting the objective or when it is no longer convenient for the parties.

The elements previously mentioned allow revising in group the different theoretical conceptions, and finally, according to Table 1 that includes the concepts related to mediation, it is identified that mediation is configured by three elements: assuming mediation as a technique, retaking the role of the mediator, and depending on the objective.

Tabla 1. Concepts related to mediation according to Vinyamata (4).

\begin{tabular}{|c|c|c|c|c|}
\hline DISCIPLINE & $\begin{array}{c}\text { OBJECT } \\
\text { OF } \\
\text { STUDY } \\
\end{array}$ & RESOURCES & $\begin{array}{c}\text { MAIN } \\
\text { ACTOR }\end{array}$ & $\begin{array}{l}\text { CONFLICTS } \\
\text { TACKLED }\end{array}$ \\
\hline Mediation & \multirow{7}{*}{ Conflict } & $\begin{array}{l}\text { The parties, with } \\
\text { the mediator's } \\
\text { help, look for } \\
\text { elements that help } \\
\text { improving } \\
\text { communication } \\
\text { with the objective } \\
\text { of reaching a } \\
\text { voluntary and } \\
\text { satisfactory } \\
\text { agreement for } \\
\text { both parties. }\end{array}$ & Mediator & $\begin{array}{l}\text { Of low and } \\
\text { moderate intensity, } \\
\text { specially family, } \\
\text { educational or } \\
\text { interpersonal } \\
\text { problems. }\end{array}$ \\
\hline Arbitration & & $\begin{array}{l}\text { Application of the } \\
\text { norm or } \\
\text { regulation in an } \\
\text { impartial manner. }\end{array}$ & Arbitrator & $\begin{array}{ll}\text { - } & \text { Commercial } \\
\text { - } & \text { Mercantile } \\
\end{array}$ \\
\hline Conciliation & & $\begin{array}{l}\text { Respect to the } \\
\text { legal framework } \\
\text { to reach an } \\
\text { agreement. }\end{array}$ & Conciliator & $\begin{array}{ll}-\quad & \text { Labor } \\
-\quad & \text { Social }\end{array}$ \\
\hline $\begin{array}{l}\text { Education in } \\
\text { values }\end{array}$ & & $\begin{array}{l}\text { Programs of } \\
\text { formal and } \\
\text { informal } \\
\text { education in the } \\
\text { educational field. }\end{array}$ & $\begin{array}{l}\text { Teacher } \\
\text { Pedagogue }\end{array}$ & $\begin{array}{l}\text { Prevention of } \\
\text { conflicts }\end{array}$ \\
\hline Therapies & & $\begin{array}{l}\text { Processes of } \\
\text { psychological } \\
\text { relevance. }\end{array}$ & Psychologist & $\begin{array}{l}\text { Treatment of } \\
\text { personal crisis }\end{array}$ \\
\hline Counselling & & $\begin{array}{l}\text { Treatment of } \\
\text { crisis. }\end{array}$ & Specialist & $\begin{array}{l}\text { Counselling in } \\
\text { personal crisis }\end{array}$ \\
\hline Coaching & & $\begin{array}{l}\text { Coaching people } \\
\text { to plan and } \\
\text { develop a } \\
\text { satisfactory life } \\
\text { style. }\end{array}$ & Coach & Help in crisis \\
\hline
\end{tabular}

Source: Vinyamata E. Aprender mediación. España: Paidós; 2003 (4).

Besides defining mediation, it is necessary to identify which are the characteristics that make it an alternative strategy. According to Boqué (6), there are four characteristics that are substantial for mediation and are part of its essence.

- Voluntariness: refers to the freedom of the parties to start or not a mediation process, as well as their freedom to abandon it once it has started. 
- Neutrality: a mediator is impartial.

- Confidenciality: both the parties and the mediator must be subject of clarification, as it can be understood in a different way by the participants, in both its meaning and scope.

- Personal character: it is mandatory the personal attendance to mediation appointments, therefore, it is not possible to attend through a representative.

With the previously mentioned, it can be seen that mediation has an identity of its own from which several models are generated like the ones shown in Table 2. It is worth mentioning that each one has certain singularities that allows it to adapt to different contexts such as medicine, according to the specific characteristics of the conflict.

Table 2. Models of mediation.

\begin{tabular}{|c|c|c|c|}
\hline $\begin{array}{c}\text { MODELS } \\
\text { OF } \\
\text { MEDIATIO } \\
\mathbf{N} \\
\end{array}$ & $\begin{array}{c}\text { LINEAR } \\
\text { (HARVARD) }\end{array}$ & $\begin{array}{l}\text { CIRCULAR- } \\
\text { NARRATIVE } \\
\text { (SARA COBB) }\end{array}$ & $\begin{array}{c}\text { TRANSFORMATIV } \\
\text { E } \\
\text { (LÉDERACH, } \\
\text { BUSCH AND } \\
\text { FOLGER) } \\
\end{array}$ \\
\hline Objective & $\begin{array}{l}\text { To reduce the } \\
\text { disagreement causes. } \\
\text { Reach a mutual } \\
\text { agreement. } \\
\text { Reduce differences. }\end{array}$ & $\begin{array}{l}\text { To work on } \\
\text { communication in } \\
\text { order to change } \\
\text { perspectives and } \\
\text { thus realities. } \\
\end{array}$ & $\begin{array}{l}\text { To transform conflict } \\
\text { and relationships. } \\
\text { To work on the } \\
\text { differences. }\end{array}$ \\
\hline Method & $\begin{array}{l}\text { Conflict ordering } \\
\begin{array}{ll}\text { 1. } & \text { Interests } \\
\text { 2. } & \begin{array}{l}\text { Objective } \\
\text { criteria }\end{array} \\
\text { 3. } & \text { Alternatives } \\
\text { 4. } & \text { Agreement } \\
& \text { options } \\
\text { 5. } & \text { Commitment } \\
\text { 6. } & \text { Relationship } \\
\text { 7. } & \text { Communicatio } \\
& \mathrm{n}\end{array}\end{array}$ & $\begin{array}{l}\text { Creation of } \\
\text { contexts to } \\
\text { facilitate solutions } \\
\text { accepted by the } \\
\text { parties. } \\
\text { 0. Pre-meeting: } \\
\text { planned by a } \\
\text { professional } \\
\text { member of the } \\
\text { team who will not } \\
\text { be the mediator. } \\
\text { 1. } \quad \text { Frame the } \\
\text { process. } \\
\text { 2. Know the } \\
\text { observatio } \\
\text { n points. } \\
\text { 3. Reflect on } \\
\text { the case. } \\
\text { Encourage } \\
\text { creativity } \\
\text { (team } \\
\text { without the } \\
\text { parties). } \\
\text { Narrate an } \\
\text { alternative } \\
\text { story } \\
\text { leading to } \\
\text { an } \\
\text { agreement } \\
\text { (change } \\
\text { the } \\
\text { observatio } \\
\text { n point). }\end{array}$ & 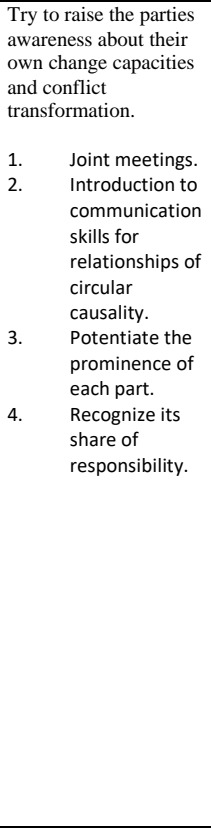 \\
\hline $\begin{array}{l}\text { Preferred } \\
\text { fields }\end{array}$ & $\begin{array}{l}\text { Business and } \\
\text { international } \\
\text { transactions. }\end{array}$ & $\begin{array}{l}\text { Familiar and } \\
\text { scholar mediation. }\end{array}$ & $\begin{array}{l}\text { Community, scholar } \\
\text { and international } \\
\text { mediation. }\end{array}$ \\
\hline $\begin{array}{l}\text { Essential } \\
\text { aspect }\end{array}$ & $\begin{array}{l}\text { To reach to negotiable } \\
\text { interests starting from } \\
\text { opposing and non- } \\
\text { negotiable positions. }\end{array}$ & $\begin{array}{l}\text { To modify } \\
\text { narrations in order } \\
\text { to get to modify } \\
\text { the reality's } \\
\text { perception. We are } \\
\text { what we tell. } \\
\end{array}$ & $\begin{array}{l}\text { To change not only the } \\
\text { situations but the } \\
\text { people as well. }\end{array}$ \\
\hline $\begin{array}{l}\text { Preferred } \\
\text { fields }\end{array}$ & $\begin{array}{l}\text { The conflict has no } \\
\text { culture, no time and no } \\
\text { person. } \\
\text { The conflict is contrary } \\
\text { to the positions. }\end{array}$ & $\begin{array}{l}\text { The conflict is a } \\
\text { mental process, } \\
\text { with a change } \\
\text { potential through } \\
\text { other mental } \\
\text { process. }\end{array}$ & $\begin{array}{l}\text { The conflict is an } \\
\text { opportunity to grow. } \\
\text { The conflict is inherent } \\
\text { to the person and the } \\
\text { society. It does not } \\
\text { disappear, it is } \\
\text { transformed. }\end{array}$ \\
\hline
\end{tabular}

\begin{tabular}{|l|l|l|l|}
\hline & $\begin{array}{l}\text { The conflict is } \\
\text { negative and must } \\
\text { disappear. }\end{array}$ & $\begin{array}{l}\text { One element is } \\
\text { enough to start the } \\
\text { change in } \\
\text { conflicting } \\
\text { systems. }\end{array}$ & \\
& & \\
\hline
\end{tabular}

Source: Munné M, Mac-Cragh P. Los 10 principios de la cultura de la mediación. Barcelona: Editorial Gra; 2006 (7).

The models suggested in Table 2 act as support systems for people in conflict or crisis, by providing culture to society facing the challenge of human diversity, not only to guarantee social order.

It is worth mentioning that in the last years there has been a rise in alternative strategies to solve disputes linked to the medical practice that allow to ensure legal compliance of this binomial and that strengthen the physician-patient relationship.

\section{CONAMED}

In the country, in the last decades, the Mexican National Commission on Medical Arbitration (CONAMED) was born as an organism of alternative justice with the purpose of reducing costs and the parties fatigue. The mediation strategy is supported on the dialogue as main tool to generate assertive communication with no need of getting to courts.

The main objective of CONAMED is to offer alternative mechanisms generated in a moment of conflict between the parties in the medical field. The conflict can be between the patient and the physician or even the family that sometimes feel attacked and the dialogue becomes difficult, and many times, inexistent.

It is worth mentioning that Netza (8) refers the following frequent causes of conflict:

- Lack of information, or misinterpretation of that information.

- Autocratic paternalistic health professional, especially physicians who insist that their criteria is the right one, ignoring the patient's and/or family's decisions.

- That health professionals prioritize the family's decisions ignoring the wishes of the patient.

- Familiar fracture where one sector supports the patient's decisions and the other does not. 
- Opposition of medical criteria, where the solution involves completely opposite actions.

Some of the types of conflicts previously mentioned are the reason for the majority of complaints and claims toward health institutions and even health professionals.

Among the main disputes in health care and attention are several aspects derived from the medical practice like mistakes and bad praxis.

It is important to say that within the Mexican context, the medical work is supervised by the government, who has to timely attend the society's claims.

\section{Conclusion}

Political, social and cultural transformations that have happened in the Mexican society lead people to reflect on the function of professional practice and invite them to rethink the roles and functions so they meet the needs of a global and changing society.

Prove of this is the role that CONAMED plays as the institution in charge of receiving claims and complaints from health care services users with the objective of developing alternative strategies to solve medical conflicts with the commitment of solving, objectively and impartially, the disputes and have a positive influence on the improvement of public and private medical practice in our country.

Political, social and cultural transformations that have happened in the Mexican society demand reflecting on the function of professional practices and invite to rethink the roles and function so they meet the needs of a global and changing society.

Prove of this is the role that CONAMED plays as the institution in charge of receiving complaints and claims from health care services users with the objective of developing alternative strategies to solve medical conflicts, aiming at settling discussions objectively and impartially, as well as having a positive influence on the improvement of public and private health care services in our country.

\section{References}

[1] Orrego P. Malpraxis médica. Acta Cancelológica [Revista online]. 2002; 31(1). Disponible en: citado además en http://www.asociacionabogadosrcs.org/congreso/ponencias 3/PonenciaEugenioLLamasPombo.html\#_ftn56.

[2] Besio M. Sobre el acto médico, Depto. Obstetricia y Ginecología. Centro de Bioética. Pontificia Universidad
Católica de Chile [Revista on-line]. 2013; (1): 25-38. Disponible

http://aebioetica.org/revistas/2003/14/1/50/25.pdf.

[3] Laín P. Antropología Médica. España: Salvat Editores; 1985.

[4] Vinyamata E. Aprender mediación. España: Paidós; 2003.

[5] Vallejo R, Guillen C. Mediación, proceso, tácticas y técnicas. España: Ediciones Pirámid.; 2006.

[6] Boqué, MC. Cultura de mediación y cambio social. Barcelona: Gedisa; 2003

[7] Munné M, Mac-Cragh P. Los 10 principios de la cultura de la mediación. Barcelona: Editorial Gra; 2006.

[9] Netza C. Protocolo para la presentación y análisis de casos clínicos ante los Comités de Ética Asistencial. Rev. Bioética y Derecho [Internet].c2013 Sep [citado 26 de agosto de 2019]; (29): 24-34. Disponible en: http://scielo.isciii.es/scielo.php?script=sci_arttext\&pid=S1 886-58872013000300004\&lng=es. http://dx.doi.org/10.4321/S1886-58872013000300004 